\title{
Convenient synthesis of C75, an inhibitor of FAS and CPT1 $\dagger$
}

Carolina Sánchez, ${ }^{a}$ Kamil Makowski, ${ }^{a, b}$ Paula Mera, ${ }^{b}$ Jaume Farràs, ${ }^{a}$ Ernesto Nicolás, ${ }^{a}$ Laura Herrero, ${ }^{b}$ Guillermina Asins, ${ }^{b}$ Dolors Serra, ${ }^{b}$ Fausto G. Hegardt, ${ }^{b}$ Xavier Ariza, ${ }^{*, a}$ and Jordi Garcia*,a

${ }^{a}$ Departament de Química Orgànica, CIBERobn and IBUB, Facultat de Química, Universitat de Barcelona, C/Martí i Franquès 1-11, 08028-Barcelona (Spain).

E-mail:xariza@ub.edu,jordigarciagomez@ub.edu

${ }^{b}$ Departament de Bioquímica i Biologia Molecular, CIBERobn and IBUB, Facultat de Farmàcia, Universitat de Barcelona, C/Joan XXIII s/n, 08028-Barcelona (Spain).

$†$ Electronic supplementary information (ESI) available. See DOI:...

Received...

\section{Table of contents entry}

A new approach to the enzyme inhibitor C75 and its temporary transformation into a phenylseleno ether derivative is disclosed. This procedure facilitates the purification, manipulation and storage of $\mathrm{C} 75$.

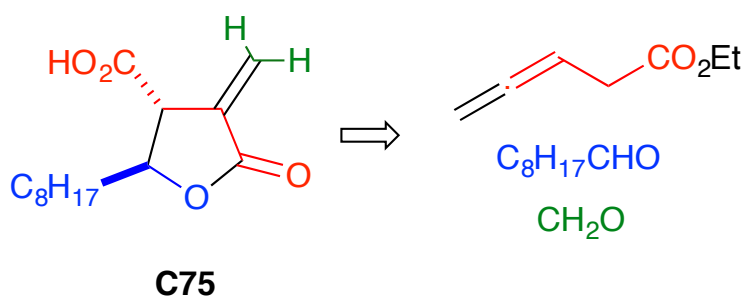




\begin{abstract}
C75 is a synthetic racemic $\alpha$-methylene- $\gamma$-butyrolactone exhibiting antitumoural properties in vitro and in vivo as well as to inducing hypophagia and weight loss in rodents. These interesting properties are thought to be a consequence of the inhibition of the key enzymes FAS and CPT1 in lipid metabolism. The need for larger amounts of this compound for biological evaluation prompted us to develop a convenient and reliable route to multigram quantities of C75 from easily available ethyl penta-3,4-dienoate 6. A recently described protocol for the addition of $\mathbf{6}$ to a mixture of dicyclohexylborane and nonanal followed by acidic treatment of the crude afforded lactone $\mathbf{8}$, as a mixture of cis and trans isomers, in good yield. The DBU-catalyzed isomerization of the methyl esters $\mathbf{9}$ arising from $\mathbf{8}$ gave a 10:1 trans/cis mixture from which the trans isomer was isolated and easily transformed into C75. The temporary transformation of C75 into a phenylseleno ether derivative makes its purification, manipulation and storage easier.
\end{abstract}

\title{
Introduction
}

C75 is a synthetic racemic compound that acts as a potent inhibitor of mammalian type I fatty acid synthase (type I FAS) and, in its CoA-adducted form, inhibits carnitine palmitoyltransferase 1 (CPT1) activity in vivo. Over the last few years, C75 as a racemic mixture of its trans diastereoisomers has been used extensively in the study of fatty acid synthesis in metabolic disorders and cancer. ${ }^{1}$

In the course of our ongoing search for potential new drugs against obesity and type 2 diabetes, ${ }^{2}$ we required multigram quantities of racemic trans $\mathrm{C} 75$ for biological testing and as starting material for the preparation of new analogues. Although C75 is commercially available, its very high price prompted us to consider the preparation of C75 in our own laboratory. Surprisingly, only one procedure for its preparation has been reported by Kuhajda et $a l .^{3}$ This procedure was based on previous work ${ }^{4}$ by Carlson et al. that uses itaconic anhydride and $p$-methoxybenzyl alcohol as starting materials. Under these conditions $\mathrm{C} 75$ is obtained as a separable mixture of C75 and its cis isomer $\mathbf{1}$. In our hands, the laborious column chromatography process required for this separation caused significant isomerization of the exocyclic double bond to the endocyclic position to give inactive 
isomer 2 (Fig. 1). Herein, we proposed an alternative straightforward scalable method for the preparation of $\mathrm{C} 75$ and its separation from $\mathbf{1}$ and $\mathbf{2}$.

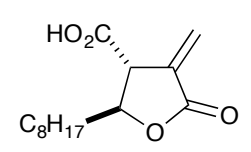

C75

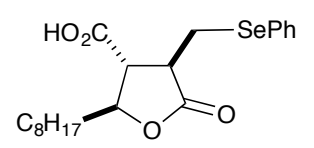

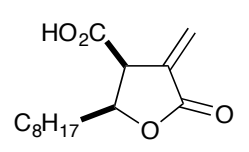

1

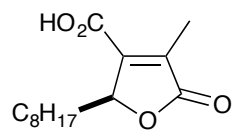

2

Figure 1. Structures of $\mathbf{C 7 5}$ and compounds $\mathbf{1}-\mathbf{3}$.

According to our retrosynthetic analysis of $\mathrm{C} 75$, the methylene group would be introduced in the last step from lactone trans-4 that would arise from the appropriate $\gamma$-hydroxyester anti-5 (Scheme 1). Taking advantage of our recent studies on the stereoselective addition of allenes to aldehydes, ${ }^{5}$ we envisaged that the hydroboration of ethyl penta-3,4-dienoate 6 with dicyclohexylborane in the presence of nonanal could afford the required anti-5. ${ }^{6}$ Herein, we report our findings in this respect.

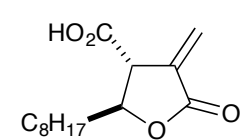

C75

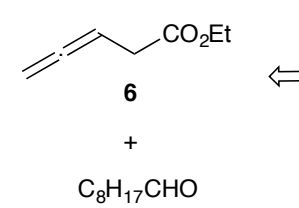

Scheme 1. Retrosynthetic analysis of $\mathbf{C 7 5}$.

\section{Results and discussion}

The allylation and crotylation of aldehydes with 2-alkenyl boranes provide attractive and versatile routes to homoallylic secondary alcohols. 2-Alkenylides derived from alkali and alkaline earth metals generally serve as the starting points for the generation of 2-alkenyl boranes. However, hydroboration of allenes might be a milder alternative for obtaining such boron reagents. Initially, the borane adds to the sterically less hindered face of the allene to 
form a transient (Z)-2-alkenylborane. However, this kinetically formed borane reagent suffers fast isomerization to the thermodynamically more stable $(E)$-2-alkenylborane at room temperature. The addition of an aldehyde to this then affords a syn homoallylic alcohol as the major product, through a 6-membered transition state. Recently, we demonstrated that the hydroboration of the allene is also possible in the presence of the aldehyde. ${ }^{5 \mathrm{~b}}$ In such conditions, the $(Z)$-borane reagent can be trapped immediately by the aldehyde leading to anti adducts. Accordingly, we expected that the treatment of a mixture of ethyl penta-3,4-dienoate 6 and nonanal with $\mathrm{Chx}_{2} \mathrm{BH}$ would led to anti-5 by trapping the transient (Z)-2-alkenylborane, (Z)-7 (Scheme 2). In contrast, the hydroboration of 6 with dicyclohexylborane $\left(\mathrm{Chx}_{2} \mathrm{BH}\right)$ followed by the addition of nonanal would afford selectively the $\gamma$-hydroxyester syn-5.

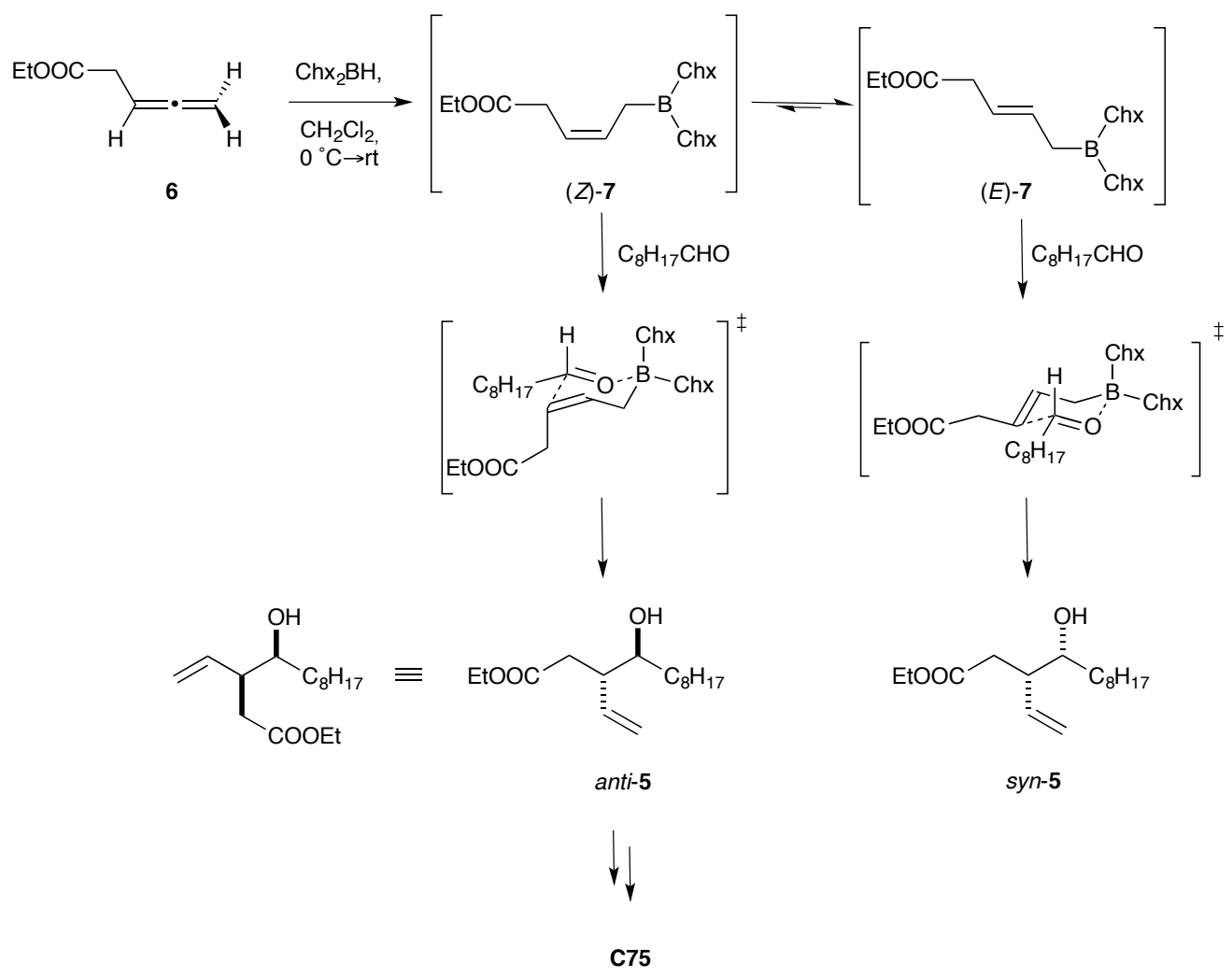

Scheme 2. Mechanism of hydroboration of $\mathbf{6}$ followed by nonanal addition.

In practice, the addition of allene 6 to a mixture of $\mathrm{Chx}_{2} \mathrm{BH}$ (1.2 equiv) and nonanal (1.2 equiv) in $\mathrm{CH}_{2} \mathrm{Cl}_{2}$ gave, after work-up (triethanolamine) and chromatographic separation, a separable mixture of hydroxyester syn-5 and the lactone trans-8 arising from anti-5 but in a disappointing 6:4 ratio (Scheme 3). Apparently, the minor anti-5 isomer formed suffers a selective lactonization during the work-up and/or chromatographic processes to give trans- 
8. The unexpected abundance of the $s y n$ isomer suggests that after the hydroboration step, isomerization of $(Z)-7$ to $(E)-7$ was faster than we expected. It is known that the allylic isomerization of the crotylboranes strongly depends on the steric hindrance of both allylic positions and the isomerization in (Z)-7 seems to be easier than in the more hindered protected allenols used in our previous work. ${ }^{5 b}$ When we heated the mixture in $\mathrm{MeOH}$ to reflux with acid catalysis, only 8 was obtained in $68 \%$ overall yield as a $6: 4$ cis/trans mixture that was difficult to separate. As expected, isolated syn-5 afforded only cis-8 under acidic conditions.

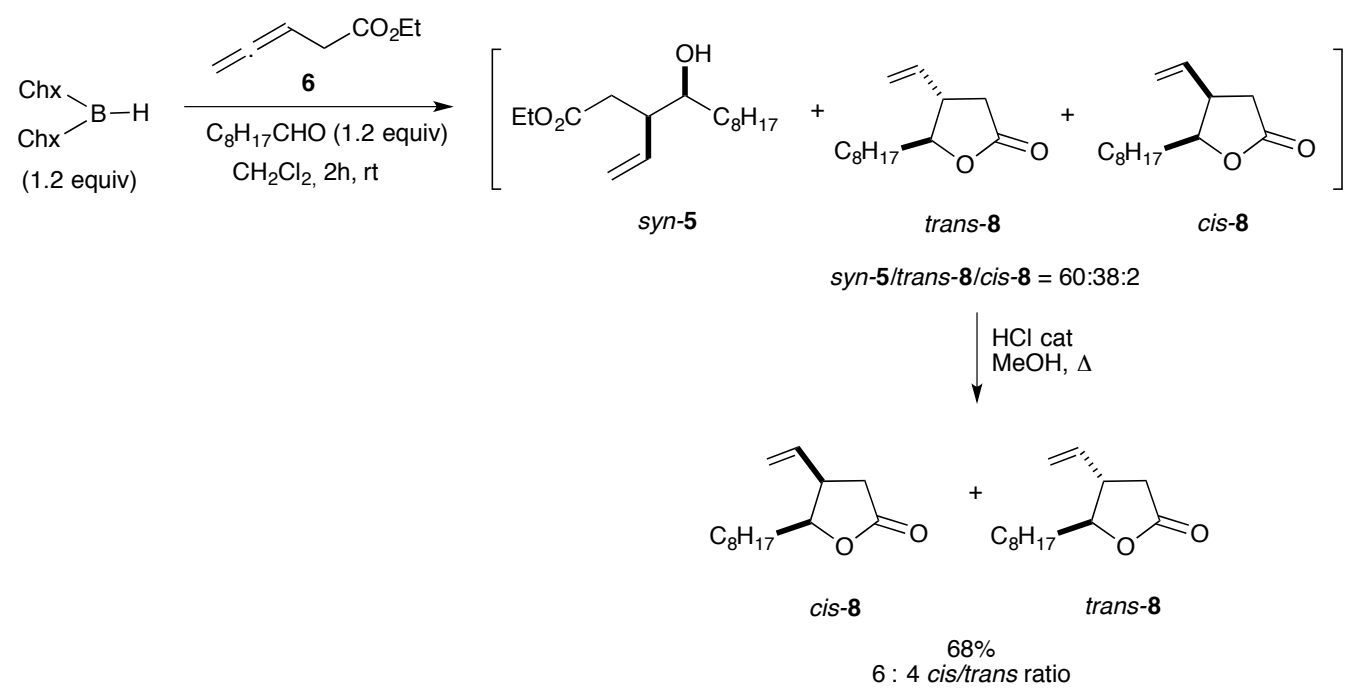

Scheme 3. One-pot synthesis of lactones 8

In an effort to improve the proportion of trans-8, the experimental conditions were revised. Lower temperatures $\left(0^{\circ} \mathrm{C}\right.$ or $\left.-20^{\circ} \mathrm{C}\right)$ slowed down $Z / E$ isomerization of 7 but hydroboration was incomplete and yields diminished. Neither changing the solvent (THF, $\left.\mathrm{Et}_{2} \mathrm{O}\right)$, or workup (triethanolamine or $\mathrm{H}_{2} \mathrm{O}_{2}$ ) nor a fine tuning of the allene/aldehyde/ $\mathrm{Chx}_{2} \mathrm{BH}$ ratio were satisfactory. Consequently, we considered the use of more hindered hydroborating agents. Both (-)-Ipc $\mathrm{BH}^{7}$ (Ipc = isopinocampheyl), and disiamylborane ${ }^{8}$ were tested since these bulky reagents are less prone to undergo boratropic isomerization providing a greater opportunity for trapping the $\mathrm{Z}$ reagent. Furthermore, by using an enantiopure boron reagent, the reaction could, in principle, become enantioselective. Unfortunately, neither of the reagents improved the trans-8/syn-5 ratio significantly but also led to lower yields (40$45 \%$ ). In addition, the GC analysis of the trans-8 obtained with (-)-Ipc $\mathrm{I}_{2} \mathrm{BH}$ revealed low enantioselectivities (55:44 ratio). 


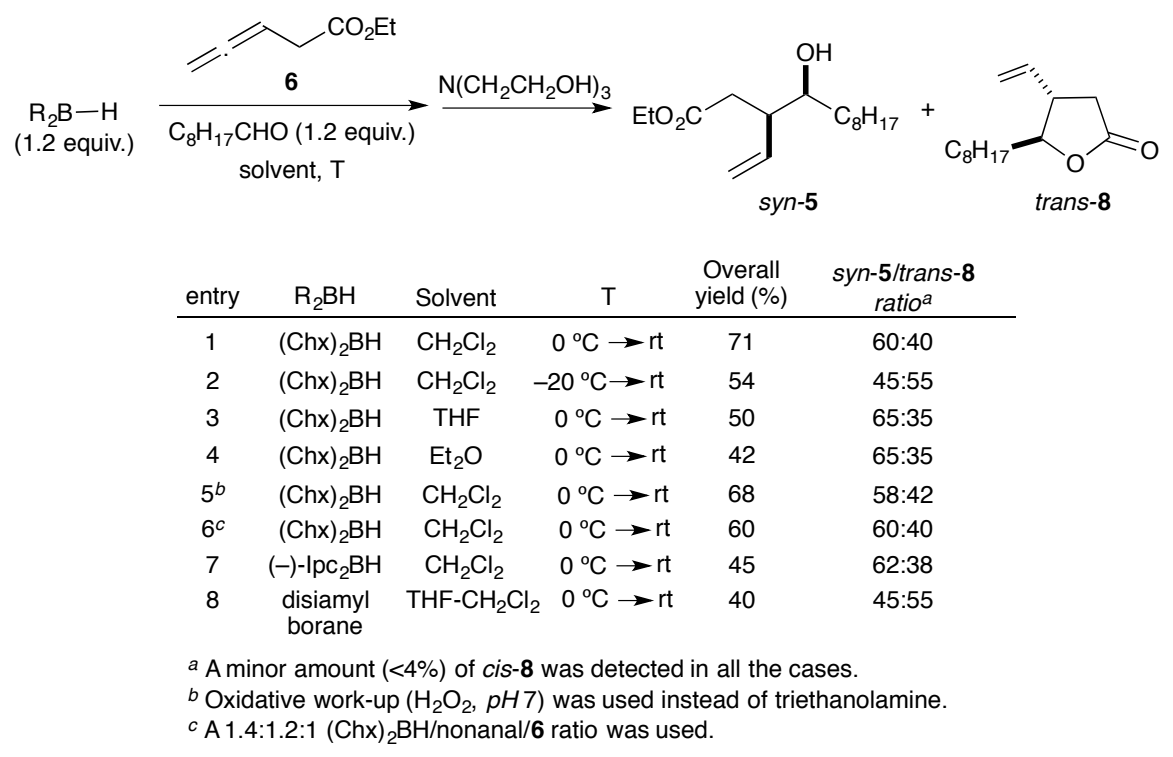

Table 1. Hydroboration-addition of 6 to nonanal by "one-pot" protocol.

On the other hand, when we performed the alternative stepwise process for comparative purposes, i.e. hydroboration of $6\left(\mathrm{CH}_{2} \mathrm{Cl}_{2}\right.$ or THF) with $(\mathrm{Chx})_{2} \mathrm{BH}$ (1.2 equiv.) followed by addition of nonanal at $-78^{\circ} \mathrm{C}$, only complex reaction mixtures containing compounds 5 or 8 in low yield $(<15 \%)$ were obtained. These results are in sharp contrast with previous ones both from our laboratory ${ }^{5}$ and others ${ }^{9}$ in which terminal allenes undergo addition to aldehydes in good yields under similar conditions. Our results suggest that, although the starting allene readily disappeared in the hydroboration step (as observed by TLC), the resulting alkenylborane decomposed at $0{ }^{\circ} \mathrm{C}$ giving a mixture of by-products. ${ }^{10}$

Consequently, we turned our attention to the former one-pot hydroboration with $\mathrm{Chx}_{2} \mathrm{BH}$ (Scheme 3). Having in hand the mixture of lactones $\mathbf{8}$, the oxidation ${ }^{11}$ of the vinyl group was performed with $\mathrm{NaIO}_{4} / \mathrm{RuCl}_{3}$ to afford almost quantitatively a mixture of acids 4 . Gratifyingly the transformation of $\mathbf{4}$ into methyl esters 9 allowed us to improve the diastereomeric ratio to 10:1 trans/cis by heating the mixture with DBU in dry toluene. The compound trans $\mathbf{- 9}$ was then easily isolated chromatographically and then hydrolyzed to obtain $>95 \%$ stereopure trans -4 . 


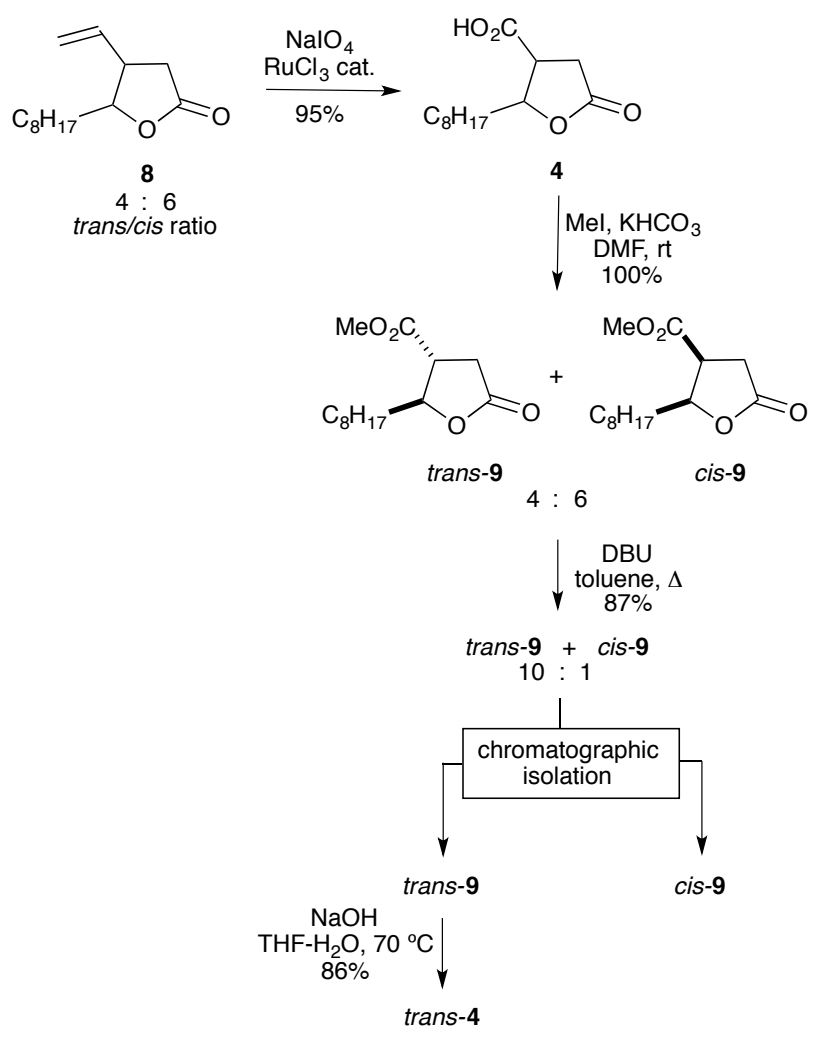

Scheme 4. Preparation of trans-4

The transformation of trans-4 into C75 was then quite straightforward (Scheme 5) and its methylenation by a known procedure ${ }^{12}$ completed the synthesis of $\mathrm{C} 75$ in a very respectable $29 \%$ overall yield.

Although C75 can be stored for months at $0{ }^{\circ} \mathrm{C}$ with no loss of activity, it is prone to suffer facile isomerization to the more stable fully conjugated lactone $\mathbf{2}$ in solution or during chromatographic purifications on silica gel. We envisaged that a phenylseleno ether derivative should be an appropriate protecting group for such a delicate exocyclic double bond. After storage and/or purification, C75 could then be regenerated under mild oxidative conditions. ${ }^{13}$ This was confirmed by treating a sample of $\mathrm{C} 75$ with $\mathrm{PhSeSePh}$ and $\mathrm{NaBH}_{4}$ in EtOH to afford the seleno derivative $\mathbf{3}$ in $90 \%$ yield. It should be noted that $\mathbf{2}$ remains unchanged under these conditions. ${ }^{14}$ Derivative 3 could be easily purified by column chromatography ${ }^{15}$ and stored in a closed flask at $\mathrm{rt}$ for more than one year. Its treatment with $30 \% \mathrm{H}_{2} \mathrm{O}_{2}$ in THF at $\mathrm{rt}$ then regenerated the desired $\mathrm{C} 75$. 


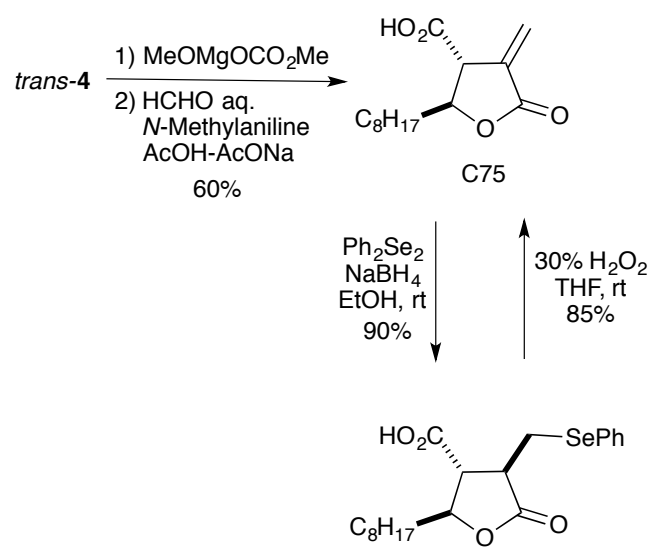

3

Scheme 5. Preparation of $\mathbf{C 7 5}$ and its temporary transformation into the phenylseleno ether derivative $\mathbf{3 .}$

In conclusion, we disclose a useful new method of preparation of C75 in 29\% overall yield based on a hydroboration ethyl penta-3,4-dienoate/addition of nonanal tandem process. The unexpected chemical instability of the transient 2-alkenylboranes was mitigated by a recently reported one-pot strategy in which the allene was hydroborated in the presence of the aldehyde. The formation of a considerable amount of undesired syn stereoisomer was overcome by transformation of the adducts into methyl esters 9. These intermediates allowed us minimize and remove the undesired stereoisomer. Finally, we report the temporary transformation of C75 into a phenylseleno derivative as a practical method for its purification and storage. We envisage the application of such phenylseleno derivatives to the preparation of new analogues of C75 in the future.

\section{Experimental}

\section{General information}

All reactions involving moisture- or air-sensitive reagents were performed in ovendried glassware under $\mathrm{N}_{2} .{ }^{1} \mathrm{H}$ NMR and ${ }^{13} \mathrm{C}$ NMR spectra were recorded on Mercury 400 or Varian Inova 300 instruments. Chemical shifts $(\delta)$ are quoted in parts per million and referenced to internal TMS for ${ }^{1} \mathrm{H} N M R$ and to $\mathrm{CDCl}_{3}(\delta 77.0 \mathrm{ppm})$ for ${ }^{13} \mathrm{C}$ NMR. Column chromatography was performed on silica gel (Merck 230-400 mesh). HRMS analyses were recorded on an Agilent LC/MSD-TOF mass spectrometer. IR spectra (wave numbers in $\mathrm{cm}^{-1}$ ) were recorded on a Nicolet 6700 FT-IR spectrometer. Ethyl penta-3,4-dienoate $(6),{ }^{16} \mathrm{Chx}_{2} \mathrm{BH},{ }^{8 \mathrm{~b}}(-)-\mathrm{Ipc}_{2} \mathrm{BH},{ }^{7}$ and disiamylborane ${ }^{8}$ were 
prepared according to literature procedures. Samples of cis-4-methylene-2-octyl-5oxotetrahydrofuran-3-carboxylic acid (1) and 4-methyl-2-octyl-5-oxo-2,5dihydrofuran-3-carboxylic acid (2) were obtained by Kuhajda's protocol ${ }^{3 a}$ for comparative purposes.

cis-4-Methylene-2-octyl-5-oxotetrahydrofuran-3-carboxylic acid (1). White solid. Mp: 81-82 ${ }^{\circ} \mathrm{C}\left(\right.$ lit. $\left.^{3 \mathrm{a}} 74-75.5{ }^{\circ} \mathrm{C}\right) ; \mathrm{R}_{\mathrm{f}}\left(\mathrm{CH}_{2} \mathrm{Cl}_{2} / \mathrm{MeOH}\right.$ 9:1) $=0.27 ;{ }^{1} \mathrm{H}$ NMR $(300 \mathrm{MHz}$, $\left.\mathrm{CDCl}_{3}\right) \delta 0.88\left(\mathrm{t}, J=6.7 \mathrm{~Hz}, 3 \mathrm{H}, \mathrm{CH}_{3}\right), 1.08-1.78\left(\mathrm{~m}, 14 \mathrm{H}, \mathrm{CH}_{2}\right), 4.03(\mathrm{dt}, J=7.6,2.2$ $\mathrm{Hz}, 1 \mathrm{H}, \mathrm{CHCOOH}), 4.65(\mathrm{td}, J=7.7,5.3 \mathrm{~Hz}, 1 \mathrm{H}, \mathrm{CHO}), 5.89$ (d, $J=2.1 \mathrm{~Hz}, 1 \mathrm{H}$, $=\mathrm{CH} H), 6.45(\mathrm{~d}, J=2.3 \mathrm{~Hz}, 1 \mathrm{H},=\mathrm{C} H \mathrm{H}) ;{ }^{13} \mathrm{C} \mathrm{NMR}: \delta 14.2,22.7,25.7,29.2,29.3$, 29.5, 31.5, 31.9, 48.9, 78.3, 125.8, 133.4, 169.1, 174.2; IR (KBr): 3000-3400, 2922, $2855,1748,1713,1663$.

4-Methyl-2-octyl-5-oxo-2,5-dihydrofuran-3-carboxylic acid (2). White solid. Mp: $113-114{ }^{\circ} \mathrm{C} ; \mathrm{R}_{\mathrm{f}}\left(\mathrm{CH}_{2} \mathrm{Cl}_{2} / \mathrm{MeOH} 8: 2\right)=0.22 ;{ }^{1} \mathrm{H} \mathrm{NMR}\left(\mathrm{CDCl}_{3}, 400 \mathrm{MHz}\right) \delta 0.81(\mathrm{t}, J=$ $\left.6.8 \mathrm{~Hz}, 3 \mathrm{H}, \mathrm{CH}_{3} \mathrm{CH}_{2}\right), 1.15-1.45\left(\mathrm{~m}, 12 \mathrm{H}, \mathrm{CH}_{2}\right), 1.60$ (m, $\left.2 \mathrm{H}, \mathrm{CH}_{2} \mathrm{CO}\right), 2.24(\mathrm{~s}, 3 \mathrm{H}$, $\left.\mathrm{CH}_{3}\right), 5.06(\mathrm{~m}, 1 \mathrm{H}, \mathrm{CHO}) ;{ }^{13} \mathrm{C} \mathrm{NMR}\left(\mathrm{CDCl}_{3}, 101 \mathrm{MHz}\right) \delta 11.2,14.2,22.8,24.9,29.3$, 29.4, 29.5, 32.0, 32.9, 81.6, 140.2, 146.8, 166.7, 172.8; IR (KBr): 3261, 2956-2854, $1744,1700,1215$.

\section{One-pot addition of ethyl penta-3,4-dienoate (6) to nonanal.}

\section{a) Using dicyclohexylborane}

A solution of $6(0.987 \mathrm{~g}, 7.79 \mathrm{mmol})$ and nonanal $(1.61 \mathrm{~mL}, 9.386 \mathrm{mmol})$ in dry $\mathrm{CH}_{2} \mathrm{Cl}_{2}(3$ $\mathrm{mL}$ ) was added via cannula to a suspension of dicyclohexylborane $(1.672 \mathrm{~g}, 9.386 \mathrm{mmol})$ in dry $\mathrm{CH}_{2} \mathrm{Cl}_{2}(4 \mathrm{~mL})$ at $0{ }^{\circ} \mathrm{C}$ under $\mathrm{N}_{2}$. The reaction mixture was allowed to warm to room temperature. After 20 hours, $2.6 \mathrm{~mL}(19.55 \mathrm{mmol})$ of triethanolamine was added and the mixture was stirred for further $15 \mathrm{~min}$. The mixture was carefully concentrated under vacuum and the resulting crude was purified by flash column cromatography (hexanes/EtOAc 9:1) affording ethyl syn-4-hydroxy-3-vinyldodecanoate syn-5 (884 mg, $3.27 \mathrm{mmol}, 42 \%)$ and 5-octyl-4-vinyldihydrofuran-2(3H)-one 8 (507 mg, $2.26 \mathrm{mmol}, 29 \%)$ as a 20:1 mixture of trans/cis lactones. 
Ethyl syn-4-hydroxy-3-vinyldodecanoate (syn-5). Colorless oil; $\mathrm{R}_{\mathrm{f}}($ hexanes/EtOAc 8:2) = 0.38; ${ }^{1} \mathrm{H}$ NMR $\left(300 \mathrm{MHz}, \mathrm{CDCl}_{3}\right): \delta 0.87\left(\mathrm{t}, J=6.7 \mathrm{~Hz}, 3 \mathrm{H}, \mathrm{CH}_{3}\right), 1.19-1.49(\mathrm{~m}, 17 \mathrm{H}, 7 \mathrm{x}$ $\mathrm{CH}_{2}$ and $\left.\mathrm{CH}_{3}\right), 2.42(\mathrm{dd}, J=14.8,8.0 \mathrm{~Hz}, 1 \mathrm{H}, \mathrm{CH} H), 2.56(\mathrm{dd}, J=14.7,6.1 \mathrm{~Hz}, 1 \mathrm{H}, \mathrm{CH} H)$, 2.57-2.68 (m, 1H, $\mathrm{CHCH}=), 3.56(\mathrm{~m}, 1 \mathrm{H}, \mathrm{CHOH}), 4.11$ (q, $\left.J=7.1 \mathrm{~Hz}, 2 \mathrm{H}, \mathrm{CH}_{2}\right), 5.09-$ $5.19\left(\mathrm{~m}, 2 \mathrm{H}, \mathrm{CH}=\mathrm{CH}_{2}\right), 5.77\left(\mathrm{ddd}, J=17.3,10.4,8.4 \mathrm{~Hz}, 1 \mathrm{H}, \mathrm{CH}=\mathrm{CH}_{2}\right) ;{ }^{13} \mathrm{C} \mathrm{NMR}(101$ $\left.\mathrm{MHz}, \mathrm{CDCl}_{3}\right): \delta 14.2,14.4,22.8,26.0,29.4,29.7,29.7,32.0,35.0,36.6,45.9,60.5,73.3$, 118.0, 136.4, 172.9; IR (film): 2924, 2854, 1781, 1167; HRMS (ESI+) calculated for $\mathrm{C}_{16} \mathrm{H}_{31} \mathrm{O}_{3}[\mathrm{M}+\mathrm{H}]^{+}:$271.2268; found: 271.2260.

trans-5-Octyl-4-vinyldihydrofuran-2(3H)-one (trans-8). Colorless oil; $\mathrm{R}_{\mathrm{f}}$ (hexanes /EtOAc 9:1) $=0.28 ;{ }^{1} \mathrm{H}$ NMR $\left(400 \mathrm{MHz}, \mathrm{CDCl}_{3}\right): \delta 0.88\left(\mathrm{t}, J=6.9 \mathrm{~Hz}, 3 \mathrm{H}, \mathrm{CH}_{3}\right), 1.23-$ $1.77(\mathrm{~m}, 14 \mathrm{H}, 7 \mathrm{xCH}), 2.44(\mathrm{dd}, J=17.2,10.5 \mathrm{~Hz}, 1 \mathrm{H}, \mathrm{CH} H), 2.68(\mathrm{dd}, J=17.2,8.3 \mathrm{~Hz}$, $1 \mathrm{H}, \mathrm{CH} H), 2.73-2.82(\mathrm{~m}, 1 \mathrm{H}, \mathrm{CHCH}=), 4.14(\mathrm{td}, J=8.3,3.8 \mathrm{~Hz}, 1 \mathrm{H}, \mathrm{CHO}), 5.13-5.23(\mathrm{~m}$, $\left.2 \mathrm{H}, \mathrm{CH}=\mathrm{CH}_{2}\right), 5.72\left(\mathrm{ddd}, J=17.2,10.2,7.9 \mathrm{~Hz}, 1 \mathrm{H}, \mathrm{CH}=\mathrm{CH}_{2}\right) ;{ }^{13} \mathrm{C} \mathrm{NMR}(101 \mathrm{MHz}$, $\left.\mathrm{CDCl}_{3}\right) \delta 14.0,22.6,25.7,29.1,29.3,29.3,31.8,33.6,35.4,46.3,84.8,117.9,135.7,175.7$; IR (film): 2924, 2854, 1779, 1365, 1216; HRMS (ESI+) calculated for $\mathrm{C}_{14} \mathrm{H}_{25} \mathrm{O}_{2}[\mathrm{M}+\mathrm{H}]^{+}$: 225.1849; found: 225.1845 .

\section{cis-5-Octyl-4-vinyldihydrofuran-2(3H)-one (cis-8)}

A solution of syn-5 (135 mg, $0.499 \mathrm{mmol})$ in $\mathrm{MeOH}(4 \mathrm{~mL})$ and $2 \mathrm{M} \mathrm{HCl}(0.5 \mathrm{~mL})$ was refluxed for $4 \mathrm{~h}$. The solution was concentred to $\sim 1 \mathrm{~mL}$ and $\mathrm{CH}_{2} \mathrm{Cl}_{2}(10 \mathrm{~mL})$ was added. The solution was washed with sat. $\mathrm{NaHCO}_{3}$, the organic layer dried $\left(\mathrm{Na}_{2} \mathrm{SO}_{4}\right)$ and the volatiles removed to give almost pure cis-8 (110 mg, 100\%). Colorless oil; $\mathrm{R}_{\mathrm{f}}$ (hexanes /EtOAc 9:1) $=0.25 ;{ }^{1} \mathrm{H}$ NMR $\left(400 \mathrm{MHz}, \mathrm{CDCl}_{3}\right): \delta 0.86\left(\mathrm{t}, J=6.8 \mathrm{~Hz}, 3 \mathrm{H}, \mathrm{CH}_{3}\right), 1.18-$ $1.63\left(\mathrm{~m}, 14 \mathrm{H}, 7 \mathrm{xCH} \mathrm{H}_{2}\right), 2.41(\mathrm{dd}, J=17.3,5.5 \mathrm{~Hz}, 1 \mathrm{H}, \mathrm{CH} H), 2.68(\mathrm{dd}, J=17.3,8.1 \mathrm{~Hz}$, $1 \mathrm{H}, \mathrm{CH} H), 3.09-3.18(\mathrm{~m}, 1 \mathrm{H}, \mathrm{CHCH}=), 4.48(\mathrm{ddd}, J=9.3,6.4,4.4 \mathrm{~Hz}, 1 \mathrm{H}, \mathrm{CHO}), 5.20-$ $5.10\left(\mathrm{~m}, 2 \mathrm{H}, \mathrm{CH}=\mathrm{CH}_{2}\right), 5.74\left(\mathrm{ddd}, J=17.0,10.3,8.7 \mathrm{~Hz}, 1 \mathrm{H}, \mathrm{CH}=\mathrm{CH}_{2}\right) ;{ }^{13} \mathrm{C} \mathrm{NMR}(101$ $\left.\mathrm{MHz}, \mathrm{CDCl}_{3}\right) \delta 14.2,22.7,25.8,29.3,29.4,29.5,31.0,31.9,34.8,43.2,83.4,118.1,134.1$, 176.4; IR (film): 2923, 2854, 1775, 1365, 1160, 920; HRMS (ESI+) calculated for $\mathrm{C}_{14} \mathrm{H}_{25} \mathrm{O}_{2}$ $[\mathrm{M}+\mathrm{H}]^{+}:$225.1849; found: 225.1854 .

\section{b) Using disiamylborane}

Borane dimethyl sulfide complex $(0.2 \mathrm{~mL}, 1.902 \mathrm{mmol})$ were slowly added to a solution of 2-methyl-2-butene in dry THF $(1.9 \mathrm{~mL}, 3.80 \mathrm{mmol})$ at $0{ }^{\circ} \mathrm{C}$ under $\mathrm{N}_{2}$. The mixture was 
warmed to room temperature and stirred for 1 hour. The solution was cooled to $-78^{\circ} \mathrm{C}$ and a solution of allene $6(200 \mathrm{mg}, 1.585 \mathrm{mmol})$ and nonanal $(327 \mu \mathrm{L}, 1.902 \mathrm{mmol})$ in dry $\mathrm{CH}_{2} \mathrm{Cl}_{2}(1 \mathrm{~mL})$ was added. The mixture was stirred for further 15 minutes at $-78^{\circ} \mathrm{C}$ and 20 hours at room temperature. The reaction was quenched by addition of triethanolamine $(0.5$ $\mathrm{mL}, 3.963 \mathrm{mmol}$ ) and the resulting solution was stirred for 1 hour. After concentration under reduced pressure the crude was purified by flash column chromatography (hexanes/EtOAc 9:1) to afford syn-5 (18\%) and trans-8 (22\%).

\section{c) Using diisopinocampheylborane}

A solution of allene $6(200 \mathrm{mg}, 1.585 \mathrm{mmol})$ and nonanal $(327 \mu \mathrm{L}, 1.902 \mathrm{mmol})$ in dry $\mathrm{CH}_{2} \mathrm{Cl}_{2}(2 \mathrm{~mL})$ was added to a cooled suspension of diisopinocampheylborane $(0.720 \mathrm{~g}$, $1.90 \mathrm{mmol})$ in dry $\mathrm{CH}_{2} \mathrm{Cl}_{2}(1 \mathrm{~mL})$ at $0{ }^{\circ} \mathrm{C}$ under $\mathrm{N}_{2}$. After 1.5 hours, the reaction was quenched by addition of triethanolamine $(0.5 \mathrm{~mL}, 3.963 \mathrm{mmol})$ and the mixture was stirred at room temperature for 1 hour. The solvent was carefully removed under vacuum and the crude was purified by flash column chromatography (hexanes/EtOAc 95:5 and 9:1) giving syn-5 (28\%) and trans-8 (17\%). Analysis of a sample of trans-8 by GC using a chiral column (Supelco Alpha Dex 120, $30 \mathrm{~m}$ x $0.25 \mathrm{~mm}, 130{ }^{\circ} \mathrm{C}, \mathrm{t}_{\mathrm{R}}=32.2 \mathrm{~min}$ and $32.4 \mathrm{~min}$ ) showed a 55:45 enantiomeric ratio.

\section{Stepwise addition of ethyl penta-3,4-dienoate (6) to nonanal.}

A solution of $6(0.494 \mathrm{~g}, 3.90 \mathrm{mmol})$ in dry $\mathrm{CH}_{2} \mathrm{Cl}_{2}(1 \mathrm{~mL})$ was added via cannula to a suspension of dicyclohexylborane $(0.836 \mathrm{~g}, 4.69 \mathrm{mmol})$ in dry $\mathrm{CH}_{2} \mathrm{Cl}_{2}(3 \mathrm{~mL})$ at $0{ }^{\circ} \mathrm{C}$ under $\mathrm{N}_{2}$. The reaction mixture was allowed to warm to room temperature. After $50 \mathrm{~min}$, the solution was cooled again to $-78{ }^{\circ} \mathrm{C}$ and nonanal $(805 \mu \mathrm{L}, 4.69 \mathrm{mmol})$ in dry $\mathrm{CH}_{2} \mathrm{Cl}_{2}(2$ $\mathrm{mL}$ ) was added. The reaction was allowed to warm to room temperature and after $1 \mathrm{~h}$ triethanolamine $(1.3 \mathrm{~mL}, 9.78 \mathrm{mmol})$ was added and the mixture was stirred for further 15 min. The resulting mixture was carefully concentrated under vacuum to give a complex crude. Attempted purification by flash column chromatography (hexanes/EtOAc 95:5 and 9:1) afforded impure fractions in which hydroxy ester $\mathbf{5}$ and lactone $\mathbf{8}$ were detected in low yields $(<15 \%$ overall yield). 


\section{Obtention of acid lactones 4 (cis/trans mixture)}

A solution of allene $6(0.307 \mathrm{~g}, 2.430 \mathrm{mmol})$ and nonanal $(0.50 \mathrm{~mL}, 2.916 \mathrm{mmol})$ in $1.5 \mathrm{~mL}$ of anhydrous $\mathrm{CH}_{2} \mathrm{Cl}_{2}$ was added to a suspension of dicyclohexylborane $(0.519 \mathrm{~g}, 2.916$ mmol) in $1.5 \mathrm{~mL}$ of anhydrous $\mathrm{CH}_{2} \mathrm{Cl}_{2}$ under $\mathrm{N}_{2}$ at $0{ }^{\circ} \mathrm{C}$. The resulting mixture was stirred for $10 \mathrm{~min}$ and then for $1 \mathrm{~h}$ at room temperature. $3 \mathrm{M} \mathrm{NaOH}(1 \mathrm{~mL})$ and $\mathrm{H}_{2} \mathrm{O}_{2}(30 \%$ in water, $1 \mathrm{~mL}$ ) were added to the reaction. After $1 \mathrm{~h}$ at room temperature it was diluted with $\mathrm{MeOH}(2 \mathrm{~mL})$ and acidified with aq $2 \mathrm{M} \mathrm{HCl}$ to $\mathrm{pH} \sim 1$ and was then heated at reflux for 3 hours. Water $(30 \mathrm{~mL})$ was added and the resulting aqueous layer was extracted with $\mathrm{CH}_{2} \mathrm{Cl}_{2}$ $(3 \times 30 \mathrm{~mL})$. The organic layer was dried $\left(\mathrm{MgSO}_{4}\right)$ and the volatiles were removed. The resulting crude lactones $\mathbf{8}(381 \mathrm{mg})$ were used without further purification in the oxidation step.

$\mathrm{NaIO}_{4}$ (2.62 g, $\left.12.2 \mathrm{mmol}\right)$ and $\mathrm{RuCl}_{3} \mathrm{H}_{2} \mathrm{O}(9 \mathrm{mg}, 0.042 \mathrm{mmol})$ were added to a stirred solution of lactones 8 in a 1:1:2 $\mathrm{CCl}_{4} / \mathrm{CH}_{3} \mathrm{CN} /$ water mixture $(12 \mathrm{~mL})$ at room temperature. After $20 \mathrm{~h}$, water $(40 \mathrm{~mL})$ was added and the mixture was extracted with $\mathrm{CH}_{2} \mathrm{Cl}_{2}(3 \times 40$ $\mathrm{mL})$. The organic extracts were dried $\left(\mathrm{MgSO}_{4}\right)$ and the volatiles were removed. The crude was filtered through a short pad of silica to obtain the corresponding mixture of acid lactones 4 (391 mg, 95\%).

\section{Preparation of compounds trans-9 and cis-9}

Methyl iodide $(100 \mu \mathrm{L}, 1.59 \mathrm{mmol})$ was added to a mixture of acid lactones $4(0.200 \mathrm{~g}$, $0.826 \mathrm{mmol})$ and $\mathrm{KHCO}_{3}(0.825 \mathrm{~g}, 8.25 \mathrm{mmol})$ in anhydrous DMF $(3 \mathrm{~mL})$ under $\mathrm{N}_{2}$ at room temperature. The mixture was stirred overnight. Water $(30 \mathrm{~mL})$ was added and the mixture was extracted with $\mathrm{Et}_{2} \mathrm{O}(3 \times 40 \mathrm{~mL})$. The combined organic extracts were washed with saturated aqueous $\mathrm{NaHSO}_{3}(20 \mathrm{~mL})$ and brine $(100 \mathrm{~mL})$. The organic layer was dried $\left(\mathrm{MgSO}_{4}\right)$ and the solvent was removed under vacuum to yield a 4:6 trans/cis mixture of esters $9(0.211 \mathrm{~g}, 100 \%)$.

1,8-Diazabicyclo[5.4.0]undec-7-ene (DBU, $120 \mu \mathrm{L}, 0.80 \mathrm{mmol}$ ) was added to a solution of the mixture of esters 9 in toluene $(10 \mathrm{~mL})$ and the solution was heated at $100{ }^{\circ} \mathrm{C}$ for $12 \mathrm{~h}$. The solution was washed with $0.02 \mathrm{M} \mathrm{HCl}(10 \mathrm{~mL})$ and brine $(10 \mathrm{~mL})$. The organic layer was dried $\left(\mathrm{MgSO}_{4}\right)$ and the solvent was removed under vacuum. The residue was purified 
by flash column chromatography $\left(\mathrm{CH}_{2} \mathrm{Cl}_{2}\right)$ to afford trans-9 $(167 \mathrm{mg}, 79 \%)$ and cis-9 (17 $\mathrm{mg}, 8 \%$ ).

Methyl trans-2-octyl-5-oxotetrahydrofuran-3-carboxylate (trans-9). Colorless oil; $\mathrm{R}_{\mathrm{f}}$ (hexanes/EtOAc 7:3) $=0.46 ;{ }^{1} \mathrm{H}$ NMR $\left(\mathrm{CDCl}_{3}, 300 \mathrm{MHz}\right): \delta 0.84-0.93\left(\mathrm{~m}, 3 \mathrm{H}, \mathrm{CH}_{3}\right), 1.18-$ $1.59\left(\mathrm{~m}, 12 \mathrm{H}, \mathrm{CH}_{2}\right), 1.64-1.84\left(\mathrm{~m}, 2 \mathrm{H}, \mathrm{CH}_{2}\right), 2.77$ (dd, $\left.J=17.6,9.5 \mathrm{~Hz}, 1 \mathrm{H}, \mathrm{CH} H \mathrm{CO}\right)$, $2.92(\mathrm{dd}, J=17.6,8.7 \mathrm{~Hz}, 1 \mathrm{H}, \mathrm{CH} H \mathrm{CO}), 3.04$ (ddd, $J=9.5,8.7,7.1 \mathrm{~Hz}, 1 \mathrm{H}, \mathrm{CHCOOMe})$, $3.75\left(\mathrm{~s}, 3 \mathrm{H}, \mathrm{CH}_{3}\right), 4.57(\mathrm{td}, J=7.3,5.0 \mathrm{~Hz}, 1 \mathrm{H}, \mathrm{CHO}) ;{ }^{13} \mathrm{C} \mathrm{NMR}\left(\mathrm{CDCl}_{3}, 101 \mathrm{MHz}\right): \delta$ 14.2, 22.7, 25.2, 29.2, 29.3 29.4, 31.9, 32.3, 35.4, 45.7, 52.8, 82.0, 171.7, 174.5; IR (film), 2953, 2926, 2855, 1790, 1739, 1201; HRMS (ESI+) calculated for $\mathrm{C}_{14} \mathrm{H}_{25} \mathrm{O}_{4}[\mathrm{M}+\mathrm{H}]^{+}$: 257.1747; found: 257.1746 .

Methyl cis-2-octyl-5-oxotetrahydrofuran-3-carboxylate (cis-9). White solid. Mp: 43-44.5 ${ }^{\circ} \mathrm{C} ; \mathrm{R}_{\mathrm{f}}$ (hexanes/EtOAc, 7:3) =0.41; ${ }^{1} \mathrm{H}$ NMR $\left(300 \mathrm{MHz}, \mathrm{CDCl}_{3}\right): \delta 0.84-0.93(\mathrm{~m}, 3 \mathrm{H}$, $\left.\mathrm{CH}_{3}\right), 1.19-1.42\left(\mathrm{~m}, 12 \mathrm{H}, \mathrm{CH}_{2}\right), 1.43-1.65\left(\mathrm{~m}, 2 \mathrm{H}, \mathrm{CH}_{2}\right), 2.66(\mathrm{dd}, J=17.6,8.7 \mathrm{~Hz}, 1 \mathrm{H}$, CHHCO), 2.90 (dd, $J=17.6,5.7 \mathrm{~Hz}, 1 \mathrm{H}, \mathrm{CH} H \mathrm{CO}), 3.44$ (ddd, $J=8.7,7.4,5.7 \mathrm{~Hz}, 1 \mathrm{H}$, CHCOOMe), 3.75 (s, 3H, $\left.\mathrm{CH}_{3}\right), 4.62(\mathrm{td}, J=7.4,6.3 \mathrm{~Hz}, 1 \mathrm{H}, \mathrm{CHO}) ;{ }^{13} \mathrm{C} \mathrm{NMR}(101 \mathrm{MHz}$, $\left.\mathrm{CDCl}_{3}\right): \delta 14.2,22.8,25.9,29.3,29.3,29.5,31.5,31.9,44.4,52.4,80.5,170.9$, 175.0; IR $(\mathrm{KBr}) 2914,2851,1775,1726,1241$; HRMS (ESI+) calculated for $\mathrm{C}_{14} \mathrm{H}_{25} \mathrm{O}_{4}[\mathrm{M}+\mathrm{H}]^{+}$: 257.1747; found: 257.1750 .

\section{trans-2-Octyl-5-oxotetrahydrofuran-3-carboxylic acid (trans-4)}

Aqueous $\mathrm{NaOH}(1 \mathrm{M}, 2 \mathrm{~mL})$ was added to a solution of trans-9 $(164 \mathrm{mg}, 0.640 \mathrm{mmol})$ in THF $(2 \mathrm{~mL})$. The mixture was heated at $70{ }^{\circ} \mathrm{C}$ until of the starting material disappeared (1 h). The mixture was partitioned by adding $\mathrm{CH}_{2} \mathrm{Cl}_{2}(5 \mathrm{~mL})$ and water $(3 \mathrm{~mL})$. The aqueous layer was extracted with $\mathrm{CH}_{2} \mathrm{Cl}_{2}(3 \mathrm{~mL})$, decanted, acidified to $p \mathrm{H} \sim 1$ with conc. $\mathrm{HCl}$ and heated to $70{ }^{\circ} \mathrm{C}$ for $1 \mathrm{~h}$. The aqueous phase was extracted with $\mathrm{CH}_{2} \mathrm{Cl}_{2}(4 \times 4 \mathrm{~mL})$ and the combined organic extracts were dried $\left(\mathrm{MgSO}_{4}\right)$. The solvent was removed under vacuum to give almost pure trans $\mathbf{- 4}$ as a white solid. Mp: $98-100{ }^{\circ} \mathrm{C} ; \mathrm{R}_{\mathrm{f}}$ (hexanes/EtOAc/HOAc 8:2:0.1) $=0.24 ;{ }^{1} \mathrm{H} \mathrm{NMR}\left(\mathrm{CDCl}_{3}, 400 \mathrm{MHz}\right): \delta 0.88\left(\mathrm{t}, J=6.7 \mathrm{~Hz}, 3 \mathrm{H}, \mathrm{CH}_{3}\right), 1.28-1.56(\mathrm{~m}$, 12H, $\mathrm{CH}_{2}$ ), 1.70-1.86 (m, $\left.2 \mathrm{H}, \mathrm{CH}_{2}\right), 2.83$ (dd, $\left.J=9.6,17.9 \mathrm{~Hz}, 1 \mathrm{H}, \mathrm{CH} H \mathrm{CO}\right), 2.95$ (dd, $J$ $=8.4,17.9 \mathrm{~Hz}, 1 \mathrm{H}, \mathrm{CH} H \mathrm{CO}), 3.07-3.14(\mathrm{~m}, 1 \mathrm{H}, \mathrm{CHRCOOH}), 4.60-4.65$ (m, 1H, CHRO); ${ }^{13} \mathrm{C} \mathrm{NMR}\left(\mathrm{CDCl}_{3}, 101 \mathrm{MHz}\right): \delta 14.2,22.8,25.3,29.3,29.3,29.5,31.9,32.0,35.5,45.3$, 
82.0, 174.7, 176.7; IR (ATR): 3000-3300, 2925, 2853, 1749, 1718, 1393, 1243, 1215, 1195, 759, 669; HRMS (ESI+) calculated for $\mathrm{C}_{13} \mathrm{H}_{22} \mathrm{NaO}_{4}[\mathrm{M}+\mathrm{Na}]^{+}: 265.1410$; found: 265.1410 .

\section{trans-4-Methylene-2-octyl-5-oxotetrahydrofuran-3-carboxylic acid (C75)}

A sample of trans $-4(85 \mathrm{mg}, 0.35 \mathrm{mmol})$ was heated in a solution of MMC (magnesium methyl carbonate, $2 \mathrm{M})$ in $\mathrm{DMF}(6 \mathrm{~mL})$ at $130-135^{\circ} \mathrm{C}$ under $\mathrm{N}_{2}$ for $45 \mathrm{~h} .6 \mathrm{M} \mathrm{HCl}(10 \mathrm{~mL})$ and $\mathrm{CH}_{2} \mathrm{Cl}_{2}(15 \mathrm{~mL})$ were added carefully. The aqueous layer was extracted with $\mathrm{CH}_{2} \mathrm{Cl}_{2}$ $(2 \times 10 \mathrm{~mL})$, the combined organic extracts were dried $\left(\mathrm{MgSO}_{4}\right)$ and the volatiles were removed to afford $100 \mathrm{mg}$ of residue. This crude was stirred with $1.2 \mathrm{~mL}$ of a freshly prepared stock solution $(1 \mathrm{~mL} \mathrm{AcOH}, 0.75 \mathrm{~mL}$ formalin, $30 \mathrm{mg} \mathrm{NaAcO}$ and $0.26 \mathrm{~mL} \mathrm{~N}$ methylaniline) for $1.45 \mathrm{~h}$. To the resulting mixture, a 10:1 aq. $\mathrm{NaCl} /$ conc. $\mathrm{HCl}$ solution (5 $\mathrm{mL})$ and $\mathrm{CH}_{2} \mathrm{Cl}_{2}(12 \mathrm{~mL})$ were added. The aqueous layer was extracted with $\mathrm{CH}_{2} \mathrm{Cl}_{2}$ $(5 \times 10 \mathrm{~mL})$. The combined organic extracts were washed with $\mathrm{LiCl} 5 \%(2 \times 4 \mathrm{~mL}), \mathrm{HCl}$ $0.02 \mathrm{M}(2 \times 4 \mathrm{~mL})$ and $\mathrm{H}_{2} \mathrm{O}(3 \times 5 \mathrm{~mL})$. The organic layer was stirred with sat. $\mathrm{NaHCO}_{3}$ solution $(5 \mathrm{~mL}$ ) for $5 \mathrm{~min}$ and then the aqueous layer was acidified with concentrated $\mathrm{HCl}$ to $p \mathrm{H} 1-2$ and was extracted with $\mathrm{CH}_{2} \mathrm{Cl}_{2}(4 \times 10 \mathrm{~mL})$. The combined organic extracts were washed with brine and dried $\left(\mathrm{MgSO}_{4}\right)$ and the solvent was removed to give $\mathrm{C} 75$ as a white solid (54 mg, $0.21 \mathrm{mmol}, 60 \%)$. Mp: 88-89 ${ }^{\circ} \mathrm{C}$ (lit., ${ }^{3 \mathrm{a}} 76-77{ }^{\circ} \mathrm{C}$ ); $\mathrm{R}_{\mathrm{f}}\left(\mathrm{CH}_{2} \mathrm{Cl}_{2} / \mathrm{MeOH}\right.$ 9:1) $=0.27 ;{ }^{1} \mathrm{H}$ NMR $\left(400 \mathrm{MHz}, \mathrm{CDCl}_{3}\right): \delta 0.88\left(\mathrm{t}, J=6.9 \mathrm{~Hz}, 3 \mathrm{H}, \mathrm{CH}_{3}\right), 1.20-1.53(\mathrm{~m}, 12$ $\left.\mathrm{H}, \mathrm{CH}_{2}\right), 1.67-1.79\left(\mathrm{~m}, 2 \mathrm{H}, \mathrm{CH}_{2}\right) 3.63$ (dd, $\left.J=5.6,2.8 \mathrm{~Hz}, 1 \mathrm{H}, \mathrm{CHCOOH}\right), 4.80$ (td, $J$ $=7.2,5.6 \mathrm{~Hz}, 1 \mathrm{H}, \mathrm{CHRO}), 6.00(\mathrm{~d}, J=2.7 \mathrm{~Hz}, 1 \mathrm{H},=\mathrm{CHH}), 6.46(\mathrm{~d}, J=2.7 \mathrm{~Hz}, 1 \mathrm{H}$,

$=\mathrm{CH} H) ;{ }^{13} \mathrm{C} \mathrm{NMR}\left(101 \mathrm{MHz}, \mathrm{CDCl}_{3}\right): \delta 14.2,22.7,24.9,29.2,29.3,29.5,31.9,35.8$, 49.6, 79.1, 126.1, 132.5, 168.5, 174.7; IR (film): 3000-3400, 2924, 2852, 1743, 1717 , 1660, 1621, 1460; HRMS (ESI+) calculated for $\mathrm{C}_{14} \mathrm{H}_{23} \mathrm{O}_{4}: 255.1591[\mathrm{M}+\mathrm{H}]^{+}$; found: 255.1587.

\section{trans,trans-2-Octyl-5-oxo-4-[(phenylselanyl)methyl]tetrahydrofuran-3-carboxylic} acid (3). A solution of $\mathrm{C} 75(0.200 \mathrm{~g}, 0.78 \mathrm{mmol})$ in EtOH $(3 \mathrm{~mL})$ was added dropwise via cannula to a mixture of $\mathrm{Ph}_{2} \mathrm{Se}_{2}(0.135 \mathrm{~g}, 0.43 \mathrm{mmol})$ and $\mathrm{NaBH}_{4}(0.035 \mathrm{~g}, 0.94$ $\mathrm{mmol})$ in EtOH ( $3 \mathrm{~mL})$ under $\mathrm{N}_{2}$ at room temperature. The resulting yellow solution was stirred $3.5 \mathrm{~h}$ and then acidified with $2 \mathrm{M} \mathrm{HCl}$ to $p \mathrm{H}=1$. Volatiles were evaporated and 
the aqueous residue was extracted with $\mathrm{CH}_{2} \mathrm{Cl}_{2}(3 \times 8 \mathrm{~mL})$. The combined organic layers were washed with $20 \% \mathrm{NH}_{4} \mathrm{Cl}$ solution $(2 \times 5 \mathrm{~mL})$ and brine $(2 \times 5 \mathrm{~mL})$, dried $\left(\mathrm{MgSO}_{4}\right)$ and the solvent was removed under vacuum. The purification of the crude by flash chromatography (hexanes/EtOAc /HOAc 70:30:1) furnished the desired product $(0.290$ g, 0.70 mmol, $90 \%)$ as a white solid. Mp: $116-118{ }^{\circ} \mathrm{C} ; \mathrm{R}_{\mathrm{f}}\left(\mathrm{CH}_{2} \mathrm{Cl}_{2} / \mathrm{MeOH} 9: 1\right)=0.44$; ${ }^{1} \mathrm{H} \mathrm{NMR}\left(\mathrm{CDCl}_{3}, 400 \mathrm{MHz}\right): \delta 0.81\left(\mathrm{t}, J=6.6 \mathrm{~Hz}, 3 \mathrm{H}, \mathrm{CH}_{3}\right), 1.16-1.48\left(\mathrm{~m}, 12 \mathrm{H}, \mathrm{CH}_{2}\right)$, 1.61-1.70 (m, 1H, CHHCHO), 1.72-1.80 (m, 1H, CHHCHO), 3.03 (dd, $J=9.2,10.2$ $\mathrm{Hz}, 1 \mathrm{H}, \mathrm{CHCOOH}), 3.09-3.15$ (m, 1H, CHHSe), 3.32-3.38 (m, 2H, CHHSe and $\mathrm{CH}-$ $\mathrm{CH}_{2} \mathrm{Se}$ ), 4.47 (td, $\left.J=8.8,4.0 \mathrm{~Hz}, 1 \mathrm{H}, \mathrm{CHO}\right), 7.17-7.19$ (m, 3H, CH(Ar)), 7.43-7.45 (m, $2 \mathrm{H}, \mathrm{CH}(\mathrm{Ar})) ;{ }^{13} \mathrm{C} \mathrm{NMR}\left(\mathrm{CDCl}_{3}, 101 \mathrm{MHz}\right) \delta 14.2,22.8,25.3,27.1,29.3,29.4,29.5$, 29.8, 31.9, 35.1, 45.5, 51.4, 79.9, 127.8, 129.2, 129.4, 133.1, 174.8, 176.4; IR (KBr): 2951-2922, 1763, 1697, 1162; HRMS (ESI+) calculated for $\mathrm{C}_{20} \mathrm{H}_{28} \mathrm{NaO}_{4} \mathrm{Se}[\mathrm{M}+\mathrm{Na}]^{+}$: 435.1045; found: 435.1039 .

\section{Preparation of C75 by oxidation of 3.}

$\mathrm{H}_{2} \mathrm{O}_{2} 30 \%(48 \mu \mathrm{L}, 0.428 \mathrm{mmol})$ was added to a stirred solution of $3(0.044 \mathrm{~g}, 0.107$ $\mathrm{mmol})$ in THF $(0.6 \mathrm{~mL})$ at room temperature. After $2.5 \mathrm{~h}$, the resulting mixture was diluted with $\mathrm{CH}_{2} \mathrm{Cl}_{2}(6 \mathrm{~mL})$ and sat. $\mathrm{NaHCO}_{3}(3 \mathrm{~mL})$ was added. The layers were separated and the aqueous layer was washed with $\mathrm{CH}_{2} \mathrm{Cl}_{2}(3 \times 3 \mathrm{~mL})$ and acidified with $6 \mathrm{M}$ $\mathrm{HCl}$ until $p \mathrm{H} \sim 1$. The aqueous layer was extracted with $\mathrm{CH}_{2} \mathrm{Cl}_{2}(4 \times 3 \mathrm{~mL})$ and the combined organic extracts were washed with brine $(8 \mathrm{~mL})$ and dried $\left(\mathrm{MgSO}_{4}\right)$. Solvent evaporation gave $\mathrm{C} 75(0.022 \mathrm{~g}, 0.087 \mathrm{mmol}, 81 \%)$ as a white solid.

\section{cis,trans-2-Octyl-5-oxo-4-[(phenylselanyl)methyl]tetrahydrofuran-3-carboxylic acid.}

A solution of $1(0.124 \mathrm{~g}, 0.49 \mathrm{mmol})$ in anh EtOH $(2 \mathrm{~mL})$ was added dropwise via cannula to a mixture of $\mathrm{Ph}_{2} \mathrm{Se}_{2}(0.084 \mathrm{~g}, 0.27 \mathrm{mmol})$ and $\mathrm{NaBH}_{4}(0.018 \mathrm{~g}, 0.49 \mathrm{mmol})$ in EtOH $(2.5$ $\mathrm{mL}$ ) under $\mathrm{N}_{2}$ at room temperature. The resulting yellow solution was stirred $3.5 \mathrm{~h}$ and was acidified with $2 \mathrm{M} \mathrm{HCl}$ to $p \mathrm{H} \sim 1$. The volatiles were evaporated and the aqueous residue was extracted with $\mathrm{CH}_{2} \mathrm{Cl}_{2}(3 \times 2 \mathrm{~mL})$. The combined organic extracts were washed with $20 \% \mathrm{NH}_{4} \mathrm{Cl}(2 \times 2 \mathrm{~mL})$, brine $(2 \times 2 \mathrm{~mL})$ and water $(2 \mathrm{~mL})$, dried $\left(\mathrm{MgSO}_{4}\right)$ and the solvent 
was removed under vacuum. The resulting crude was purified by flash column chromatography (hexanes/EtOAc /HOAc 70:30:1) to give $0.166 \mathrm{~g}$ of the desired product (0.403 mmol, 83\%) as a white solid. Mp: 87-88 ${ }^{\circ} \mathrm{C}$; $\mathrm{R}_{\mathrm{f}}$ (hexanes/EtOAc 8:2) $=0.23 ;{ }^{1} \mathrm{H}$ $\operatorname{NMR}\left(400 \mathrm{MHz}, \mathrm{CDCl}_{3}\right): \delta 0.87\left(\mathrm{t}, J=6.9 \mathrm{~Hz}, 3 \mathrm{H}, \mathrm{CH}_{3}\right), 1.13-1.69\left(\mathrm{~m}, 14 \mathrm{H}, \mathrm{CH}_{2}\right)$, 3.10-3.18 (m, 1H, CHCOOH), 3.34-3.41 (m, 2H, $\left.\mathrm{CH}_{2} \mathrm{Se}\right), 3.60$ (t, $J=8.6 \mathrm{~Hz}, 1 \mathrm{H}$, $\left.\mathrm{CHCH}_{2} \mathrm{Se}\right), 4.70(\mathrm{td}, J=8.6,4.3 \mathrm{~Hz}, 1 \mathrm{H}, \mathrm{CHO}), 7.34-7.21(\mathrm{~m}, 3 \mathrm{H}, \mathrm{CH}(\mathrm{Ar})), 7.62-$ 7.45 (m, 2H, CH(Ar)); $\left.{ }^{13} \mathrm{C} \mathrm{NMR} \mathrm{(101} \mathrm{MHz,} \mathrm{CDCl}_{3}\right): \delta 14.2,22.8,25.8,26.8,29.3,29.5$, 31.7, 31.9, 42.8, 49.2, 77.7, 125.5, 127.9, 129.5, 133.2, 174.5, 175.2. IR (KBr): 3198, 2920, 2853, 1746, 1653, 1407, 1143; HRMS (ESI+) calculated for $\mathrm{C}_{20} \mathrm{H}_{28} \mathrm{NaO}_{4} \mathrm{Se}$ $[\mathrm{M}+\mathrm{Na}]^{+}:$435.1045; found: 435.1039 .

\section{Acknowledgements}

The authors would like to thank Ministerio de Educación y Ciencia of Spain (CTQ20099692 and SAF2011-30520-C02-01) and CIBERobn for funding. K.M. also thanks Institut de Biomedicina de la Universitat de Barcelona (IBUB) for a fellowship.

\section{Notes and references}

1) More than 300 citations can be found in the literature on the biological activity of $C 75$ in recent years. For very recent references, see: $(a)$ M. T. Rahman, K. Nakayama, M. Rahman, H. Katagiri, A. Katagiri, T. Ishibashi, M. Ishikawa, K. Iida, N. Nakayama, Y. Otsuki, S. Nakayama and K. Miyazaki, Brit. J. Cancer, 2012, 107, 300-307; (b) A. P. Bahtt, S. R. Jacobs, A. J. Freemerman, L. Makowski, J. C. Rathmell, D. P. Dittmer and B. Damania, Proc. Natl. Acad. Sci. U. S. A., 2012, 109, 11818-11823; (c) C. Hountondji, K. Buligyn, A. Woisard, P. Tuffery, J. B. Crechet, M. Pech, K. H. Nierhaus, G. Karpova and S. Baouz ChemBioChem, 2012, 13, 1791-1797.

2) P. Mera, A. Bentebibel, E. López-Viñas, A. G. Cordente, C. Gurunathan, D. Sebastián, I. Vázquez, L. Herrero, X. Ariza, P. Gómez-Puertas, G. Asins, D. Serra, J. Garcia and F. G. Hegardt, Biochem. Pharmacol., 2009, 77, 1084-1095. 
3) (a) F. P. Kuhajda, G. R. Pasternak, C. A. Townsend and N. S. Mani PCT Int. Appl. WO9718806 A1 19970529, 1997; (b) F. P. Kuhajda, E. S. Pizre, J. N. Li, N. S. Mani, G. L. Frehywot and C. A. Townsend, Proc. Natl. Acad. Sci. U. S. A., 2000, 97, 3450-3454. (c) For a enzymatic resolution of the methyl ester of C75, see: K. Chakrabarty, C. Forzato, P. Nitti, G. Pitacco, E. Valentin, Lett. Org. Chem., 2010, 7, 245-248.

4) R. M. Carlson and A. R. Oyler, J. Org. Chem., 1976, 41, 4065-4069.

5) (a) X. Ariza, J. Cornellà, M. Font-Bardia, J. Garcia, J. Ortiz, C. Sánchez and X. Solans, Angew. Chem. Int. Ed., 2009, 48, 4202-4205; (b) C. Sánchez, X. Ariza, J. Cornellà, J. Farràs, J. Garcia and J. Ortiz, Chem.- Eur. J., 2010, 16, 11535-11538.

6) Although borane or alkylboranes can reduce aldehydes, this reaction is relatively slow at low temperature and a dialkylborane and an aldehyde are compatible at $\mathrm{rt}$ for short periods. See: A. Pelter, K. Smith, in Comprehensive Organic Chemistry, ed. D. H. R. Barton and W. D. Ollis, Pergamon, Oxford, 1979, vol. 3, pp. 689-940.

7) H. C. Brown and N. N. Joshi, J. Org. Chem., 1988, 53, 4059-4062.

8) (a) J. A. Sinclair and H. C. Brown, J. Org. Chem., 1988, 41, 1078-1079. (b) H. C. Brown, Organic Syntheses via Boranes, 1975, Wiley, NY.

9) See, for instance: (a) G. Narla and H. C. Brown, Tetrahedron Lett., 1997, 38, 219-222;

(b) R. Pragani and W. R. Roush, Org. Lett., 2008, 10, 4613-4616.

10) Large amounts of the starting aldehyde could be detected in the crude product. A series of experiments using (-)-(Ipc $)_{2} \mathrm{BH}$, cathecolborane, cathecolborane in the presence of Wilkinson's catalyst or diisiamylborane did not improve these results.

11) P. H. J. Carlsen, T. Katsuki, V. S. Martin and K. B. Sharpless, J. Org. Chem., 1981, 46, 3936-3938.

12) M. M. Murta, M. B. M. de Azevedo and A. E. Greene, Synth. Commun., 1993, 23, 495503.

13) P. Barbetti, G. Fardella, I. Chiappini, V. Scarcia and A. Candriani, Eur. J. Med. Chem. 1989, 24, 299-305. 
14) Preliminary attempts using $S$ instead of Se failed. Although the phenylthio ether derivative and its corresponding sulfoxide were easily obtained, the relatively high temperatures required to regenerate $\mathrm{C} 75$ caused the concomitant migration of the double bond leading to compound 2.

15) A sample of cis compound 1 obtained by Kuhajda's method ${ }^{3 a, b}$ was transformed into its phenylseleno derivative. We then checked that this derivative could be separated chromatographically from $\mathbf{3}$ and from $\mathbf{2}$, demonstrating that cis compound $\mathbf{1}$ could be also removed from $\mathrm{C} 75$ by this method.

16) M. Kimura, S. Tanaka and Y. Tamaru, Bull. Chem. Soc. Jpn., 1995, 68, 1689-1705. 